\title{
Mutation of amphioxus $P d x$ and $C d x$ demonstrates conserved roles for ParaHox genes in gut, anus and tail patterning
}

Yanhong Zhong ${ }^{1 \dagger}$, Carlos Herrera-Úbeda ${ }^{2,3+}$, Jordi Garcia-Fernàndez ${ }^{3}$, Guang Li $i^{1 *}$ and Peter W. H. Holland ${ }^{2^{*}}$ (D)

\begin{abstract}
Background: The homeobox genes $P d x$ and $C d x$ are widespread across the animal kingdom and part of the small ParaHox gene cluster. Gene expression patterns suggest ancient roles for $P d x$ and $C d x$ in patterning the throughgut of bilaterian animals although functional data are available for few lineages. To examine evolutionary conservation of $P d x$ and $C d x$ gene functions, we focus on amphioxus, small marine animals that occupy a pivotal position in chordate evolution and in which ParaHox gene clustering was first reported.
\end{abstract}

Results: Using transcription activator-like effector nucleases (TALENs), we engineer frameshift mutations in the $P d x$ and $C d x$ genes of the amphioxus Branchiostoma floridae and establish mutant lines. Homozygous $P d x$ mutants have a defect in amphioxus endoderm, manifest as loss of a midgut region expressing endogenous GFP. The anus fails to open in homozygous $C d x$ mutants, which also have defects in posterior body extension and epidermal tail fin development. Treatment with an inverse agonist of retinoic acid (RA) signalling partially rescues the axial and tail fin phenotypes indicating they are caused by increased RA signalling. Gene expression analyses and luciferase assays suggest that posterior RA levels are kept low in wild type animals by a likely direct transcriptional regulation of a Cyp26 gene by Cdx. Transcriptome analysis reveals extensive gene expression changes in mutants, with a disproportionate effect of $P d x$ and $C d x$ on gut-enriched genes and a colinear-like effect of $C d x$ on Hox genes.

Conclusions: These data reveal that amphioxus $P d x$ and $C d x$ have roles in specifying middle and posterior cell fates in the endoderm of the gut, roles that likely date to the origin of Bilateria. This conclusion is consistent with these two ParaHox genes playing a role in the origin of the bilaterian through-gut with a distinct anus, morphological innovations that contributed to ecological change in the Cambrian. In addition, we find that amphioxus Cdx promotes body axis extension through a molecular mechanism conserved with vertebrates. The axial extension role for $C d x$ dates back at least to the origin of Chordata and may have facilitated the evolution of the post-anal tail and active locomotion in chordates.

Keywords: Cephalochordate, Branchiostoma, Homeobox, Cambrian, Endoderm, Tail, Retinoic acid, Hox cluster, Cyp26

\footnotetext{
* Correspondence: guangli@xmu.edu.cn; peter.holland@zoo.ox.ac.uk

†Yanhong Zhong and Carlos Herrera-Úbeda contributed equally to this work.

${ }^{1}$ State Key Laboratory of Cellular Stress Biology, School of Life Sciences,

Xiamen University, Xiamen, China

${ }^{2}$ Department of Zoology, University of Oxford, Oxford OX1 3SZ, UK

Full list of author information is available at the end of the article
}

(c) The Author(s). 2020 Open Access This article is licensed under a Creative Commons Attribution 4.0 International License, which permits use, sharing, adaptation, distribution and reproduction in any medium or format, as long as you give appropriate credit to the original author(s) and the source, provide a link to the Creative Commons licence, and indicate if changes were made. The images or other third party material in this article are included in the article's Creative Commons licence, unless indicated otherwise in a credit line to the material. If material is not included in the article's Creative Commons licence and your intended use is not permitted by statutory regulation or exceeds the permitted use, you will need to obtain permission directly from the copyright holder. To view a copy of this licence, visit http://creativecommons.org/licenses/by/4.0/ The Creative Commons Public Domain Dedication waiver (http://creativecommons.org/publicdomain/zero/1.0/) applies to the data made available in this article, unless otherwise stated in a credit line to the data. 


\section{Background}

The discovery that three homeobox genes, Gs $x, P d x$ and $C d x$, are organised in a small gene cluster raised the possibility that these genes might act in a coordinated way. This ParaHox cluster was first described in the amphioxus Branchiostoma floridae [1], and later in human, several other vertebrates, an echinoderm, a hemichordate and two molluscs [2-8]. The cluster has broken in many taxa through genomic rearrangements or gene losses $[1,3,9,10]$. The $P d x$ gene, also called $P d x 1, X l o x$, Lox, Ipf1, IdxI or Stf1, is expressed in developing gut endoderm in vertebrates, with sharp anterior and posterior limits, and later in the pancreas and where the duodenum meets the stomach [11-13]. In amphioxus embryos, $P d x$ is also expressed strongly in the midgut endoderm and, puzzlingly, in two putative receptor cells in the neural tube $[1,14]$. The latter lie adjacent to a large pigment cell $[1,15]$ and comprise the first photosensory organ of Hesse (dorsal ocellus) to develop [16]. The amphioxus $C d x$ gene is also expressed in the gut, more posteriorly where the anus will form, and in other posterior tissues at early developmental stages [1]. Similarly, vertebrate $C d x$ genes are expressed caudally, including the posterior gut, although multiple paralogues have subtly different patterns and additional expression sites [17-19]. Gsx is expressed primarily in neural tissue in amphioxus, Drosophila and mouse [1].

Together with data from echinoderms, annelids and molluscs, these patterns led to the hypothesis that ParaHox genes were components of an ancient system for patterning the bilaterian gut $[1,20-23]$. The origin of a 'through-gut', with the mouth, digestive regions and anus, may have facilitated the evolution of predation and active burrowing, key drivers of animal diversification in the Cambrian [1, 20, 24] (but see [25]). To test this hypothesis, we need to know if ParaHox genes consistently specify region-specific fate, instructing cells to differentiate according to their head to tail position. Such a role has been suggested for vertebrate $P d x$. Mutation of both $P d x$ alleles results in the absence of a pancreas in mice and humans [12, 26-28], conditional deletion in mouse causes homeotic-like transformation of endoderm cells [13], and ectopic expression in chick causes endoderm cells to change molecular identity and behaviour [29]. $P d x$ has a similar role in sea urchin larvae, where morpholino knockdown inhibits the formation of the sphincter between the midgut and hindgut [22, 30]. In adult mammals, the Pdx protein is a transcriptional activator of insulin and other genes in $\beta$ cells of the endocrine pancreas [31]. No insights are possible from Drosophila or nematodes as they have lost $P d x$, while functional data are difficult to obtain in other invertebrates.

For $C d x$ genes, there is evidence for a role in gut patterning in several taxa. For example, heterozygous mutation of mouse $C d x 2$ causes homeotic-like transformation of posterior gut cells [32] and inhibiting $C d x$ function in sea urchin development allows posterior gut cells to express a more anterior marker [22]. In Drosophila, $C d x$ is necessary for the invagination of the hindgut [33], and Caenorhabditis elegans Cdx has roles in the development of the rectum [34]. A second role for $C d x$ genes in body axis or tail extension is also seen in some taxa, including mice, Xenopus and zebrafish [18, 35-37], an ascidian [38], and short-germ arthropods Artemia, Tribolium and Gryllus [39, 40]. There is no similar function in Drosophila, however, which may be because $C d x$ was recruited into a novel gene network patterning the rapidly developing long-germ band embryo [41]. While roles in the gut and tail may be shared between distant phyla, there are also taxon-specific roles. Thus, mutations in mouse $C d x 1$ or $C d x 2$ cause homeotic transformations of mesodermally derived vertebrae, at least in part by altering Hox gene expression [18, 42], and interfering with $C d x$ function in Xenopus causes disruption to neural patterning [37, 43]. In Drosophila, $C d x$ also specifies fate of the cells forming the anal plates on the exterior of the most posterior segment [44]. Similarly, many cell types are affected by mutation of $C d x$ (pal-1) in the nematode Caenorhabditis elegans, including posterior epidermal rays [45].

Expression of Gsx is variable between taxa, making inference of its ancestral role in bilaterians difficult. The larvae of some annelids and a mollusc show clear Gsx expression around the forming mouth, consistent with a general link between ParaHox genes and the through-gut $[9,23,46]$. This pattern, however, is not seen in all molluscs nor in ecdysozoans [47]. Wollesen et al. [47] have therefore argued that Gsx expression in the anterior nervous system was more likely an ancestral bilaterian trait, with recruitment into foregut a derived character of some taxa. Either way, deuterostomes such as amphioxus are probably not suitable for inferring ancestral roles of Gsx as the deuterostome mouth may not be homologous to the mouth of ancestral bilaterians [20].

Experimental data from a diversity of invertebrates are necessary to evaluate which roles of $P d x$ and $C d x$ are conserved between taxa and to evaluate their ancestry. Key questions are whether these genes specify region-specific cell fate in the gut and formation of the anus. Since there is no living outgroup to bilaterians that possesses a homologous through-gut, it is necessary to address this question using ingroups from each bilaterian clade. The recent development of TALEN mutagenesis methods applicable to amphioxus has opened up an opportunity to investigate these functions in this animal occupying a pivotal phylogenetic position [48, 49]. 


\section{Results}

Generation of stable $P d x$ and $C d x$ mutant lines in amphioxus

We deduced gene structures for amphioxus $P d x$ and $C d x$ and designed constructs encoding TALEN pairs targeted to the first coding exon of each (Fig. 1; Additional file 1: Figs. S1-S6). For each gene, two TALEN mRNAs were co-injected into unfertilised eggs of B. floridae and successful mutagenesis detected by PCR on pools of neurula stage embryos (Additional file 1: Table S1, Fig. S7). Remaining embryos were reared to maturity to generate mosaic F0 animals; founders were spawned and mutations typed by PCR on sperm or pools of neurulae generated by outcrossing. Embryos from F0 $\times$ wild type crosses were reared to maturity to generate F1 heterozygous mutants; these lines were expanded by crossing with wild type animals, rearing embryos to maturity and intercrossing offspring.

We generated amphioxus lines with 4-bp, 11-bp and 13-bp deletions $(4 \Delta, 11 \Delta, 13 \Delta)$ in $P d x$ (Fig. 1). Each deletion causes a frameshift predicted to give a protein comprising 31-33 amino acids of wild type protein followed by peptide sequence with no strong similarity to any known protein (Additional file 1: Fig. S8). We generated a $C d x$ mutant line with a 7-bp deletion $(7 \Delta)$ predicted to give a short peptide comprising the first 5 amino acids of $C d x$ plus 4 additional amino acids before a stop codon (Fig. 1; Additional file 1: Fig. S9). None of the predicted products contains a homeodomain.
$P d x$ is necessary for correct spatial differentiation of the midgut

Embryos derived from crosses between heterozygous $P d x$ 4 $\Delta$ mutants, and crosses between $P d x$ mutant lines, generated pools of morphologically identical embryos; genotyping revealed these include homozygotes, heterozygotes and wild type with no significant reduction in frequency of homozygous mutants (18/ 96; chi square $p=0.16)$. Since $P d x$ is strongly expressed in the gut and the first Hesse organ receptor cells in 13-h neurulae, we tested whether marker genes for these tissues were affected in $P d x$ mutants. In situ hybridisation revealed no difference in expression of Mop (melanopsin, expressed in the Hesse organ receptors; Fig. 2a, b) or Mitf (expressed in the adjacent pigment cell; Fig. 2c, d). Dorsal views show that the two receptors cells (Fig. 2a', b') and single pigment cell (Fig. 2c', d') are present in mutants. We also detected no difference in expression pattern in $P d x$ itself, $C d x$ or Ilp1 (insulin-like peptide gene) in the endoderm of neurulae (Fig. 2e-j). Later in development, however, a morphological phenotype was visible in mutants when viewed under fluorescent illumination. In wild type and heterozygote larvae, endogenous green fluorescence is detected in cirri around the mouth and in a clearly delineated patch of the midgut endoderm, noted here for the first time. In contrast, in $4 \Delta / 4 \Delta, 4 \Delta / 11 \Delta$ and $11 \Delta / 13 \Delta$ mutant larvae, clear fluorescence is seen only in buccal cirri. The difference is first detectable at the 5 gill

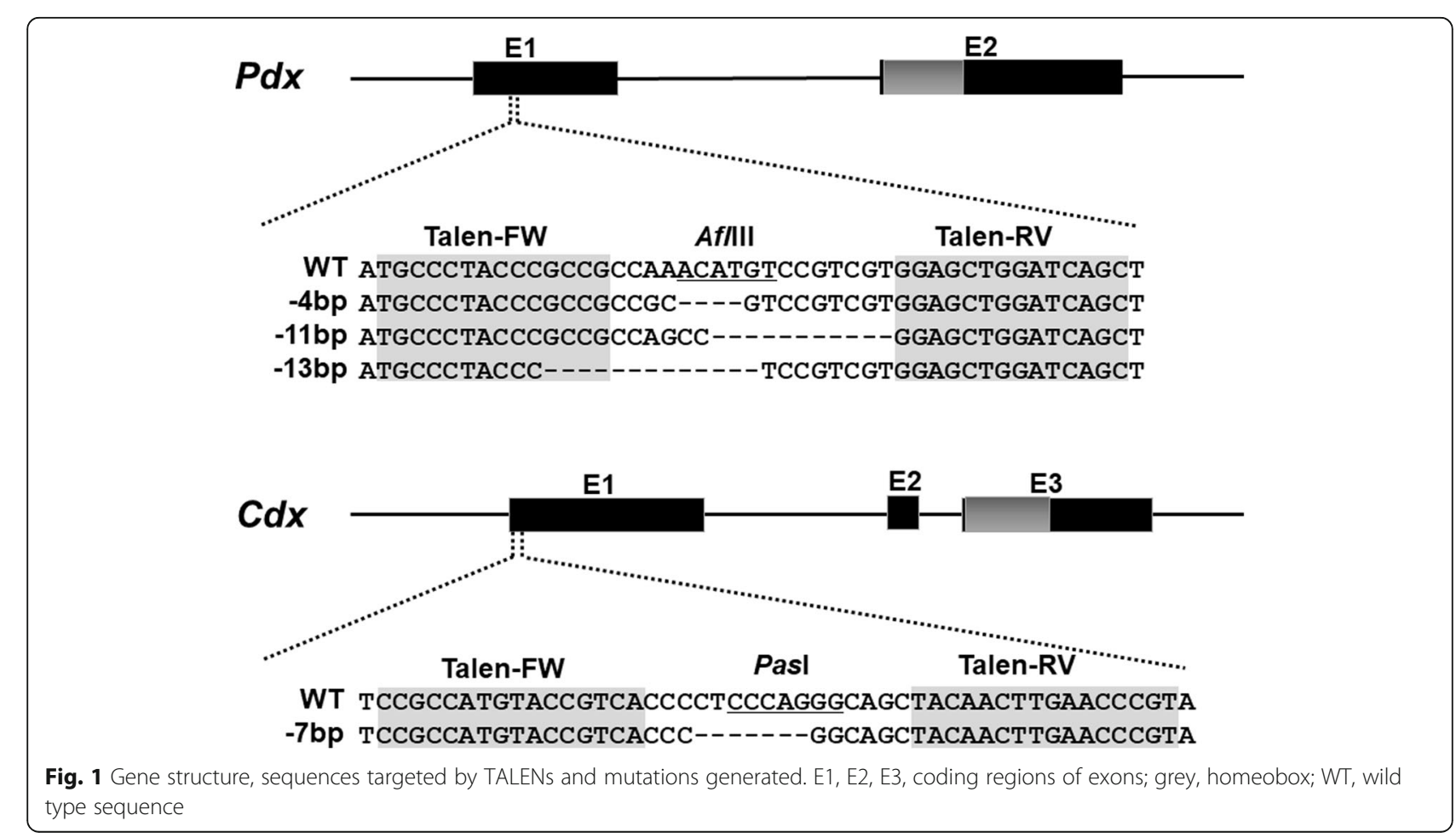




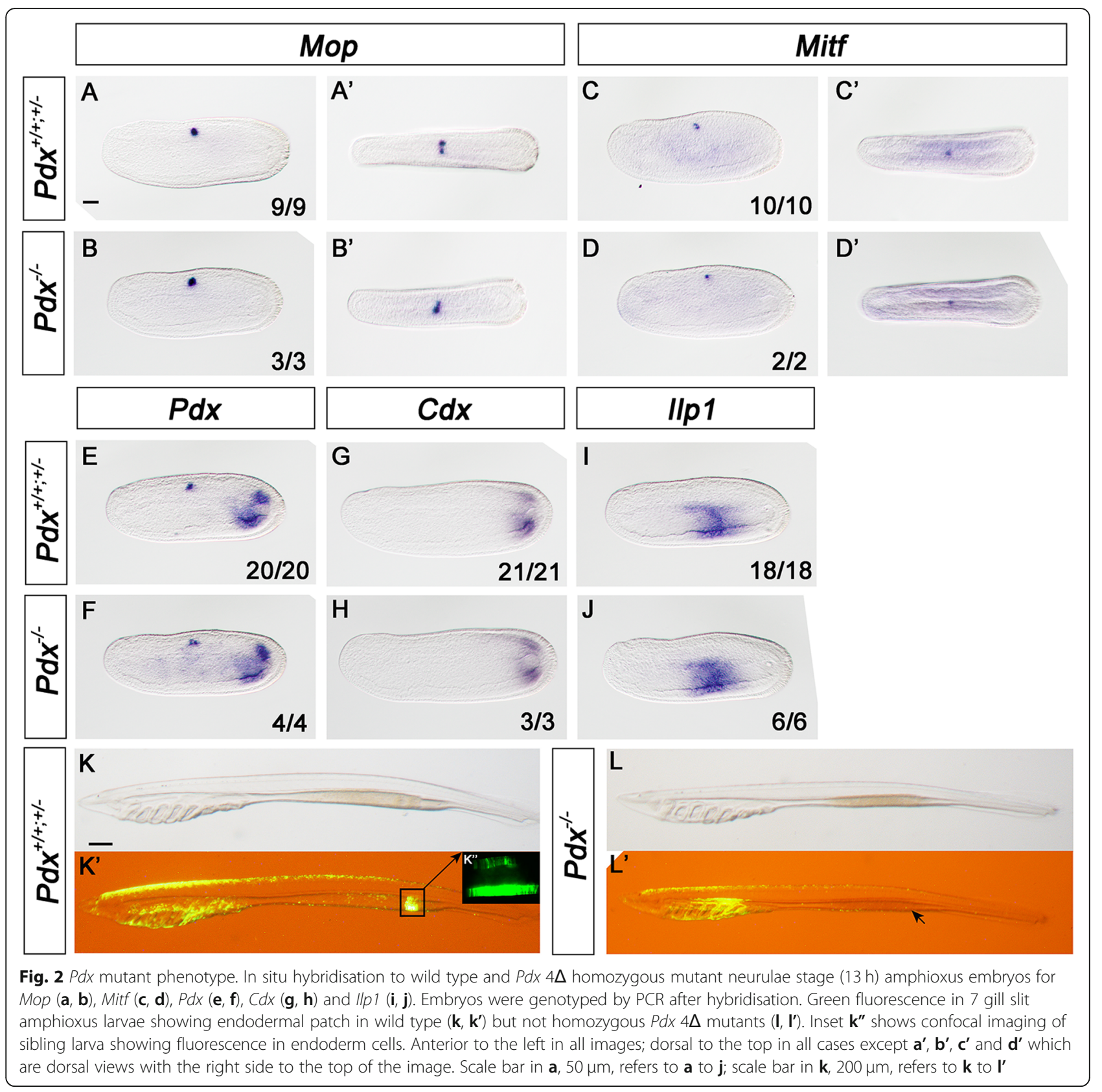

slit stage (6 to 16 days development depending on batch) and persists to larvae with many gill slits (around 46 days; Fig. 2k, 1, Additional file 1: Fig. S10, S11).

\section{$C d x$ is necessary for the formation of the anus and posterior axial extension}

Homozygous $C d x^{-/-}$mutants are identical to wild type amphioxus in external appearance through gastrula and neurula stages, and until the mouth opens around $24 \mathrm{~h}$ post-fertilisation (Fig. 3; Additional file 1: Fig. S12). Starting at the 2 to 3 gill slit stage (30 to $40 \mathrm{~h}$ post-fertilisation), a morphological difference gradually begins to be evident as truncation of the body axis in homozygous mutants (Fig. 3a, b). As development proceeds, the posterior of the animal continues to extend only in wild type and heterozygous larvae, enhancing the phenotypic difference. By the 4 gill slit stage, homozygous mutants are approximately half the length of wild type larvae (Additional file 1: Fig. S13).

A second morphological difference becomes evident around the 3 gill slit stage in the gut. In homozygous mutants, the gut remains closed by the epithelial cell layer of the endoderm; in wild type animals, the anus perforates to generate the through-gut (Fig. 3c, d). When cultured algal cells are provided to 2-day and 


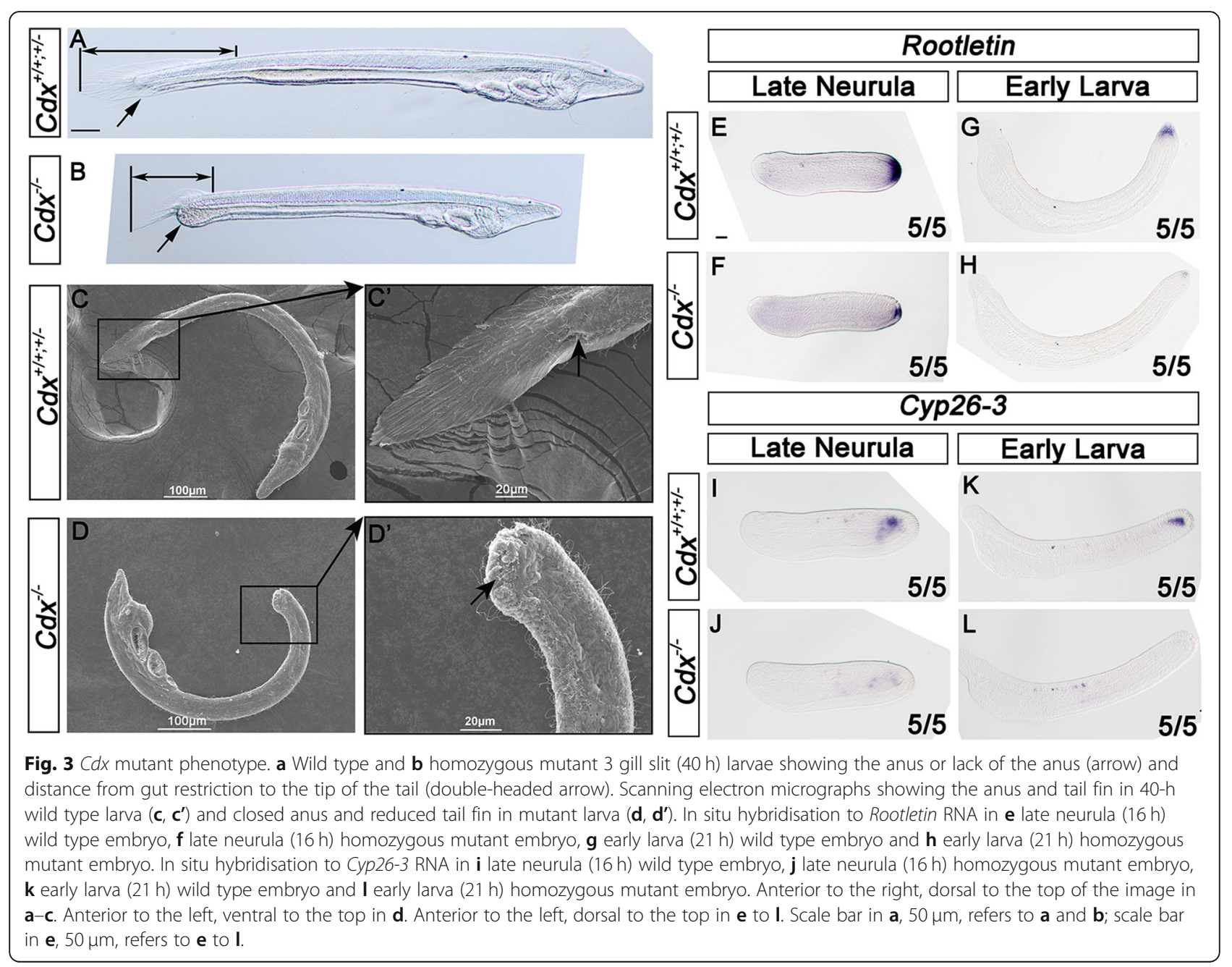

3-day larvae, mutant larvae take up food material and in some animals the closed anus ruptures leaving a ragged terminus. The tail fin is also markedly reduced in mutants and develops from a smaller zone of the posterior ectoderm; this effect is most marked ventrally (Fig. 3a, b). The development of the amphioxus tail fin is driven by the extension of specialised epidermal cells containing long intracellular ciliary rootlets containing a coiled-coil protein Rootletin [50-52]. We find the Rootletin gene is expressed by fewer cells in mutant than in control sibling larvae (Fig. 3e-h). This alteration of Rootletin gene expression is consistent with a smaller number of epidermal cells being specified to differentiate into tail fin in $C d x$ mutant animals. The expression of a posteriorly expressed gene Cyp26-3, encoding a retinoic acid-degrading enzyme, is also greatly reduced in $C d x$ mutant embryos (Fig. 3i-l). We infer that $C d x$ is necessary for fate specification of posterior ectoderm cells, for formation of the anus and for tail extension.

\section{Cdx acts via the retinoic acid pathway in amphioxus} posterior development

The imperforate anus, tail truncation, reduced Rootletin expression and tail fin phenotype observed in $C d x$ mutant larvae are similar to a suite of changes caused by exogenous treatment of amphioxus larvae with retinoic acid (RA) [51, 53]. We therefore asked whether $C d x$ mutation caused these phenotypes through an increase in RA in the posterior region.

To test if dampening RA signalling partially rescues the mutant phenotype, we treated embryos derived from $C d x$ heterozygote crosses with BMS493, an inverse agonist of the pan-retinoic acid receptor (RAR; Fig. 4). Homozygous mutant larvae treated with BMS493 had enlarged tail fins compared to untreated mutants, especially dorsally, with the fin developing from more epidermal cells (Fig. 4b, d). Posterior growth of the body increased marginally but the anus did not open. In wild type and heterozygous embryos, BMS493 treatment gave the opposite phenotype to $C d x$ mutation (Fig. $4 \mathrm{a}, \mathrm{c}$ ): an 


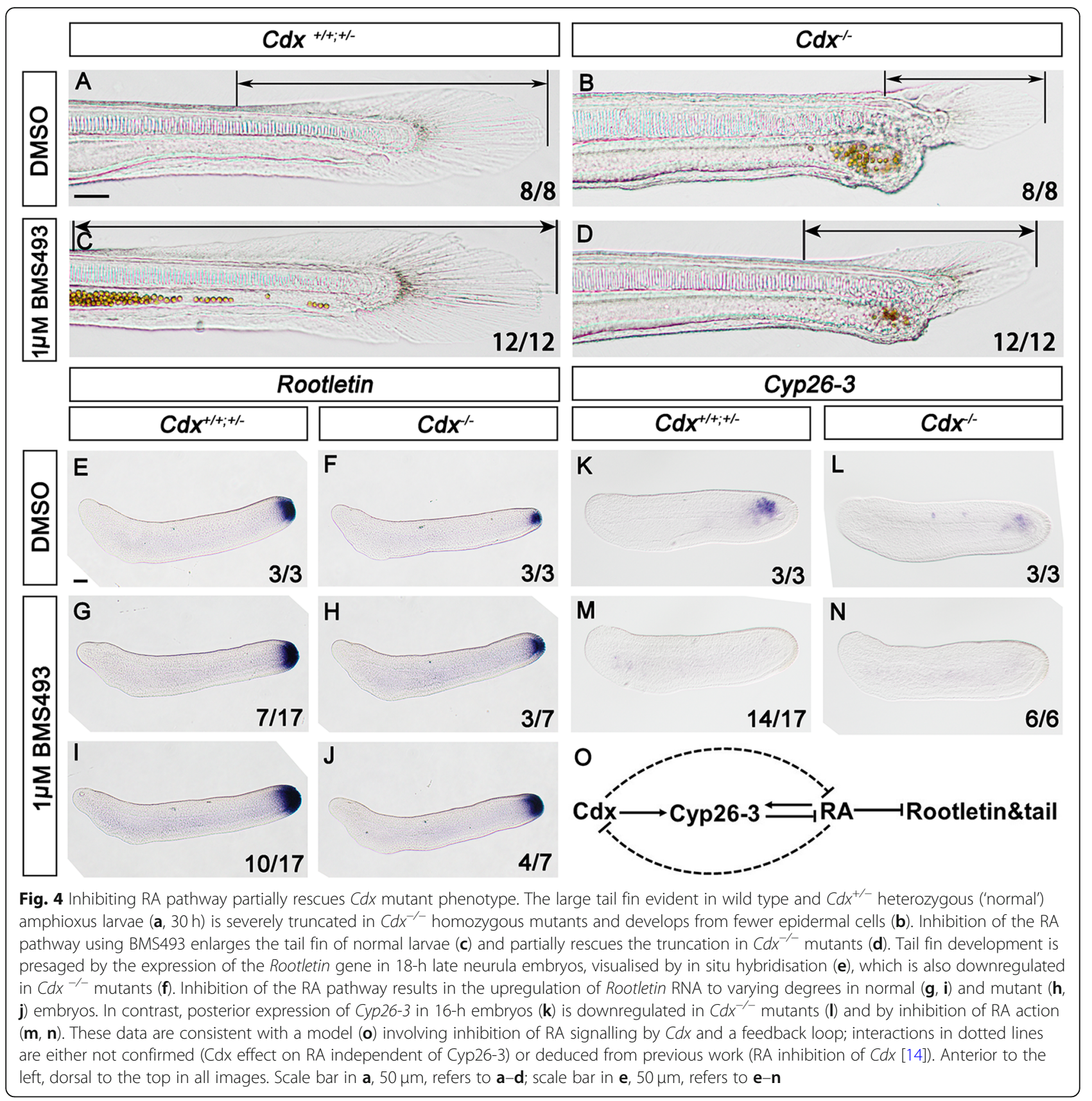

enlarged larval tail fin derived from a larger region of posterior ectoderm (see also [53]). These phenotypes were presaged by subtle changes to expression of the Rootletin gene at earlier developmental stages (Fig. $4 \mathrm{e}-\mathrm{j}$ ). We infer, therefore, that the role of $C d x$ in tail fin formation and tail extension acts, at least in part, through the RA pathway.

We examined a key player in the RA pathway, a cytochrome P450 family 26 (Cyp26) gene encoding an enzyme that degrades and clears excess RA [54]. Amphioxus has three Cyp26 genes, derived from cephalochordate-specific duplication $[53,55,56]$
(Additional file 1: Fig. S14, S15). In B. floridae, we find that Cyp26-3 is expressed posteriorly at the neurula stage (Fig. $4 \mathrm{k}$ ), unlike the pattern previously reported in B. lanceolatum [53]. In homozygote $C d x$ mutants, posterior Cyp26-3 expression is downregulated but not abolished (Fig. 41); treatment with BMS493 also downregulates Cyp26-3 expression, to a more extreme degree (Fig. $4 \mathrm{~m}, \mathrm{n}$ ). To investigate if Cyp26 genes are direct transcriptional targets of $\mathrm{Cdx}$ in amphioxus (as in mouse [57]), we injected unfertilised amphioxus eggs with a luciferase reporter gene construct driven by $3.1 \mathrm{~kb}$ of Cyp26-3 upstream sequence and assayed luciferase at 
the late neurula stage. The sequence includes several putative Cdx-binding sites (Additional file 1: Fig. S16) of which two have a close match to a consensus [58]; mutation of either or both decreases luciferase activity consistent with Cdx-binding positively regulating Cyp26-3 expression (Fig. 5; Additional file 1: Tables S3, S4).

These results suggest that a major role of $C d x$ expression is to ensure RA activity is kept at a low level in the posterior part of the amphioxus embryo, at least in part via positive regulation of Cyp26-3. Downregulation of Cyp26-3 expression by BMS493 is consistent with a feedback loop between RA and Cyp26 activity as previously shown in zebrafish [59-61] (Fig. 4o).

\section{Effects of $\mathrm{Cdx}$ and Pdx mutation on amphioxus transcriptome}

To examine the downstream molecular consequences of $P d x$ and $C d x$ mutation, we sequenced transcriptomes of mutant larvae soon after morphological phenotypes are evident: 5 gill slits for $P d x^{-/-}$and $2-3$ gill slits $(34 \mathrm{~h}$ and $42 \mathrm{~h}$ ) for $\mathrm{Cdx}^{-/-}$(42 $\mathrm{h}$ described below; mixed analysis in Additional file 2: Supplementary Data). Comparisons

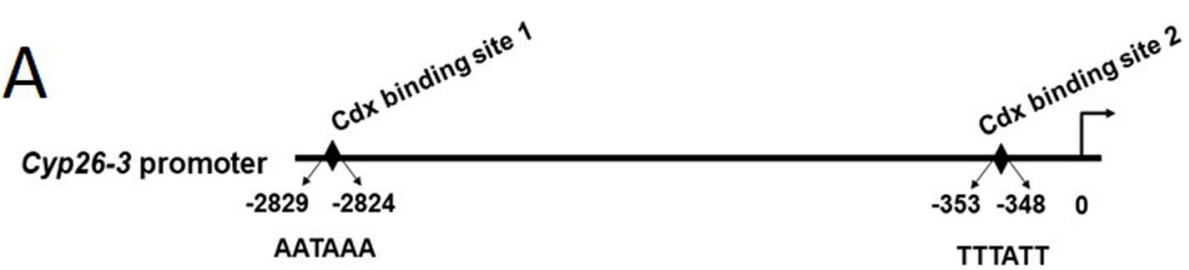

Constructs \#

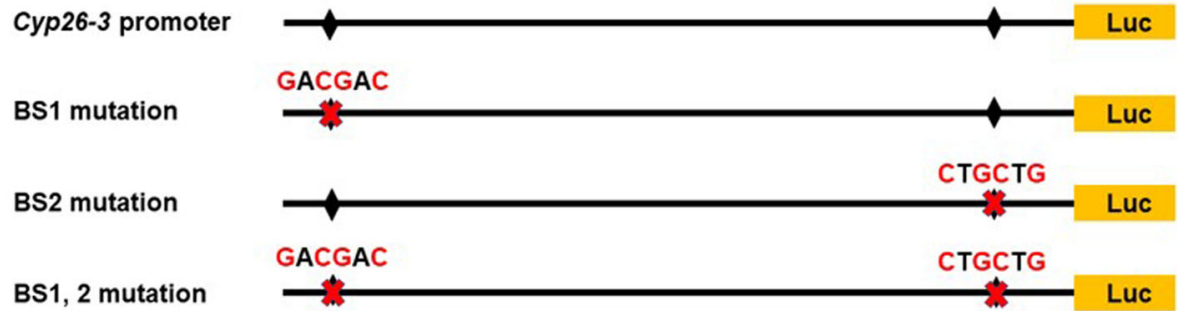

B

30

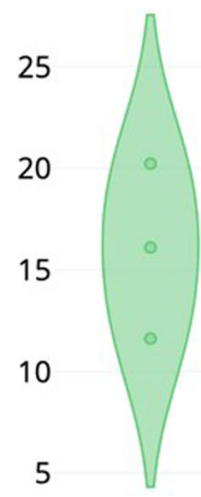

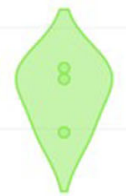

0

Сур26-3

BS1

BS2

BS1,2

PGL3

Uninjected

Fig. 5 Reporter gene analysis of Cyp26-3. a Region 5' of Cyp26-3 gene showing two putative Cdx-binding sites (BS1, BS2). Numbers are distance before start codon. Four reporter gene constructs were tested in amphioxus embryos with 0, 1 or 2 Cdx sites mutated. b Violin plot showing relative levels of luciferase expression for each construct, a control luciferase vector PGL3 without Cyp26-3 sequence, and uninjected control (values in Additional file 1: Table S4) 
were made to transcriptome data from mixed wild type and heterozygous siblings to identify direct and indirect targets of $C d x$ and $P d x$ that are up- or downregulated after mutation (Fig. 6a, b; Additional file 1: Fig. S17, S18).

We first asked which of the multiple amphioxus GFPencoding genes $[62,63]$ are affected in $P d x$ mutants. We found 11 contigs encoding GFP that were significantly downregulated (1.8 to 8.3 fold); 10 derive from tandemly duplicated amphioxus GFP genes that cannot be distinguished using short read data: GFP-8, GFP-10, GFP-12 and GFP-13 [63] (Additional file 1: Table S5). We conclude that one or more of these closely related GFP genes were affected when regionalisation of the gut was disrupted by $P d x$ mutation (Fig. 6c).

Second, we asked if signalling pathways were disrupted by ParaHox gene mutation. In $P d x^{-/-}$mutants, we detect significant changes to expression of genes encoding components of the insulin-signalling pathway $(\sim 1.6$ fold downregulation of two IGFBP contigs; 1.4 fold upregulation of ILPR [64]), but not the gut-expressed Ilp1 gene itself (Fig. 6c; Additional file 1: Table S6). In $C d x^{-/-}$mutants, we found downregulation of intracellular lipidbinding protein $(i L B P)$ genes, which in vertebrates includes $C R A B P$ (cellular retinoic acid-binding protein), $C R B P$ (cellular retinol-binding proteins) and FABP (fatty acid-binding proteins). In amphioxus, these have undergone extensive independent duplications $[56,65]$. The contigs affected by $C d x$ mutation correspond to amphioxus iLBP4 (formerly called CRABP [66]; 4.2 to 13.5 fold downregulation) and iLBP6 (1.6 fold downregulation; Fig. 6d; Additional file 1: Table S7). The biochemical activities of these genes are unclear; it is possible that one or both encode proteins that bind RA, inhibiting the RA pathway [56]. Downregulation of $i L B P$ genes in $C d x$ mutants suggests a second possible mechanism through which $C d x$ suppresses RA activity in the posterior of amphioxus: through positive regulation of $i L B P$ s. Consistent with disrupted tail formation, which persists through development, we find the Rootletin gene is downregulated in the transcriptome of $C d x$ mutants (Additional file 1: Table S7). We detect no significant change to expression levels of FGF or Wht genes, RAR, RXR or RALDH (Additional file 1; Additional file 2: Supplementary Data), but an increase in expression of Brachyury-2 in $C d x$ mutants (Additional file 1: Table S7).

Third, we examined the effect of amphioxus $C d x$ mutation on Hox genes because in vertebrates the role of $C d x$ genes in body axis elongation is mediated, at least in part, through activation of central and some posterior Hox genes [18, 43, 67, 68]. Vertebrate $C d x$ genes may also have repressive effects on the most anterior Hox genes giving a colinear-like response: in Xenopus tropicalis, perturbation of $C d x$ gene activity caused the upregulation of paralogy groups 1 and 2 Hox genes and downregulation of paralogy groups 5 to $10 / 11$ [19]. In amphioxus, Hox genes differ greatly in expression intensity in normal embryos [69-71] (Additional file 1: Table S8, Fig. S19, S20). Despite these quantitative differences, we detect a significant colinear-like response of Hox genes to amphioxus $C d x$ gene activity. In amphioxus $C d x^{-/-}$mutants, Hox-1 expression is upregulated (1.4 fold); Hox2, Hox3 and Hox4 are unaffected; Hox 5 and Hox6 are mildly downregulated; and Hox7 is strongly downregulated, although not each change is significant when genes are analysed individually (Fig. 6e; Additional file 1: Table S8, Fig. S21). This colinear-like response is consistent with amphioxus $C d x$ in normal development activating central and posterior Hox genes and repressing anterior Hox genes as part of an axis patterning system.

\section{$P d x$ and $C d x$ mutation affects gut-associated gene expression}

To investigate further the association between $P d x$ and $C d x$ genes and the development of the gut, we tested whether gene sets affected by mutations include a high proportion of 'gut-enriched' genes. We used published B. lanceolatum transcriptome data [69] to define 2083 gut-enriched genes, represented by 4705 contigs in our study. These are genes with far higher expression in level in the gut than in most other adult tissues. We find 482 are differentially expressed in $P d x^{-/-}$mutants and 218 in $C d x^{-/-}$mutants (37 in common; Additional file 2: Supplementary Data). This equates to $8.3 \%$ of the $P d x$ differentially expressed contigs and $15.3 \%$ of the $C d x$ differentially expressed contigs (Fig. 6f), a significant enrichment (Additional file 1: Fig. S22). Hence, mutation of $P d x$ or $C d x$ has a disproportionate and significant effect on the expression of gut-enriched genes.

We also used this dataset to investigate the nature of changes that occurred in the gut of $P d x^{-/-}$mutants. In the set of 482 gut-enriched contigs with altered expression in mutants, we identified 218 annotated proteincoding genes (Additional file 2: Supplementary Data). These include homologues of vertebrate proteins with well-characterised roles in gut function, including the digestive enzyme chymotrypsin (1.5 fold downregulation), a mucin that coats epithelia (1.9 fold downregulation), a glycosidase enzyme used for starch digestion (1.5 fold upregulation) and a proton-coupled transporter for intestinal absorption of folates (1.5 fold upregulation); Additional file 1: Table S9.

\section{Discussion}

The development of technologies for generating targeted mutations has great potential in comparative and evolutionary developmental biology. The most widely used 


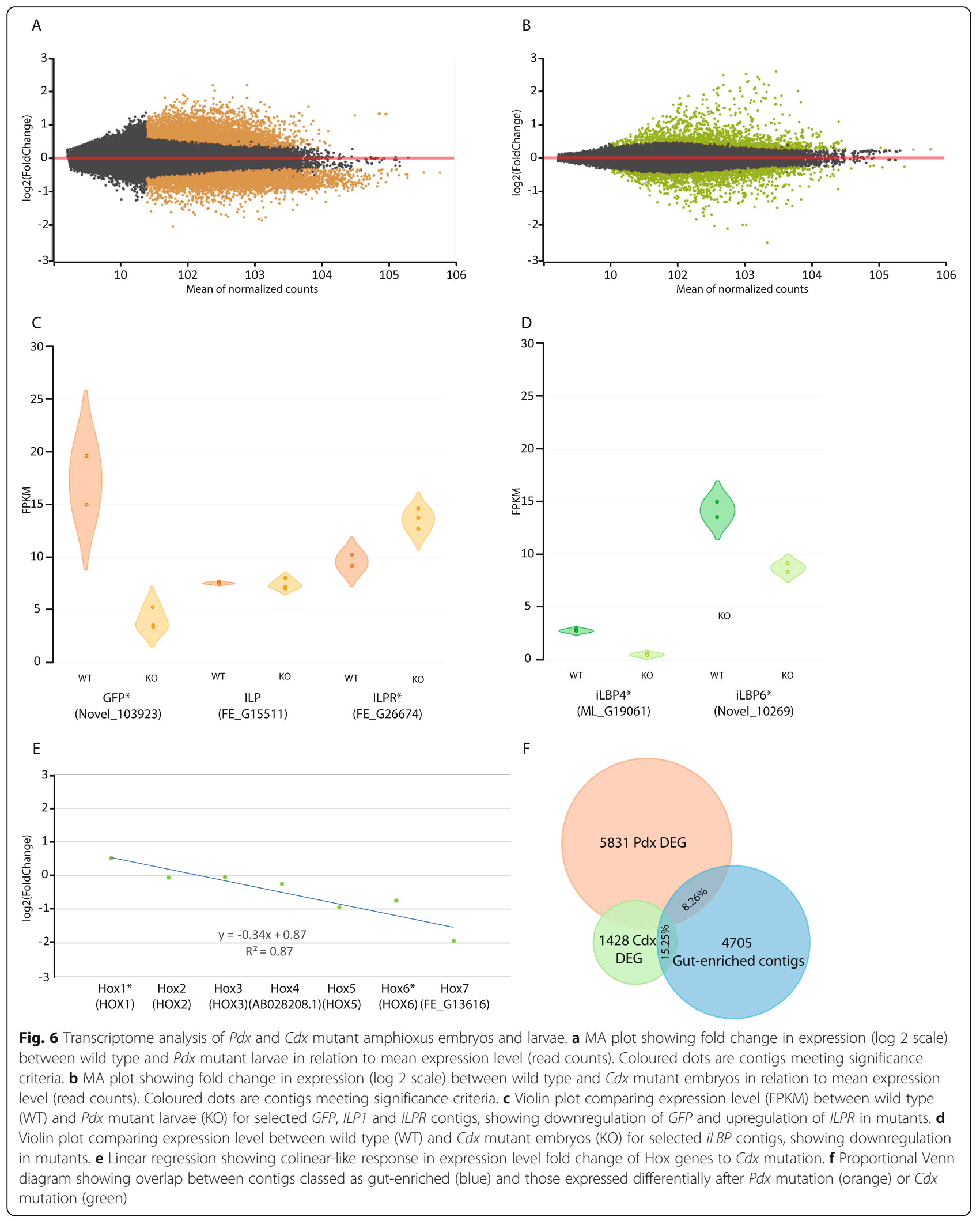


technology is based on CRISPR/Cas9, but this has not yet been applied successfully to cephalochordates. In contrast, TALENs have been used to generate inherited mutations in B. floridae [48, 49]. The method is efficient and reproducible, although not straightforward in amphioxus because of the practical difficulties of rearing from egg to adult and long generation times (4 to 6 months for B. floridae; much longer for B. lanceolatum). Here we report the introduction of germline mutations into two ParaHox genes, $P d x$ and $C d x$. Each produces a clear phenotype. We do not know if all are complete null mutations or if alternative start codon usage, perhaps at low frequency, generates a hypomorphic allele. This is a possibility for $P d x$ since the mutant phenotype is subtle and not evident at embryonic stages, even though $P d x$ has no detectable maternal RNA $[1,14,69]$. Despite this caveat, the mutations allow robust conclusions to be drawn about important roles of amphioxus $P d x$ and $C d x$ genes, although they may not reveal every function.

Descriptive work has previously suggested that $P d x$ and $C d x$ genes might have functions in specific regions of the gut, notably the midgut for $P d x$ and the posterior gut or anus for $C d x$. One of the earliest regional markers in amphioxus gut is $I l p 1$, expressed from the pharyngeal region to the midgut from gastrula to neurula, overlapping but larger than the $P d x$ domain [72, 73]. We found that mutation of amphioxus $P d x$ did not alter Ilp1 transcript abundance in neurulae or larvae. Even if $P d x$ does not specify the Ilp1 domain in early embryos, this does not exclude the possibility of $P d x$ being a transcriptional regulator of the Ilp1 gene at later stages or in adults, comparable to $P d x$ regulation of insulin in the vertebrate pancreas [74]. A later regional marker in amphioxus endoderm is a stripe of endogenous green fluorescence, evident in the midgut from the 5 gill slit stage to larvae with many gill slits (around 46 days of development). Confocal imaging confirmed this is not fluorescence from ingested algae as it is present inside endoderm cells. Previous studies involving UV excitation of amphioxus larvae and adults have described green fluorescence primarily in ovaries and buccal cirri $[62,75]$ attributed to the presence of multiple GFP genes [62,63]. To our knowledge, the stripe in larval gut has not been described previously, and it proved to be a fortuitous marker of endoderm regionalisation. The most striking phenotype we observed in $P d x^{-/-}$mutant amphioxus was the absence of the GFP stripe. Transcriptome analysis reveals the endogenous gut GFP is encoded by one or more of an array of very similar genes (GFP-8, GFP10, GFP-12, GFP-13). We interpret loss of the GFP stripe, and lower abundance of transcripts, as the consequence of incorrect cell fate specification in a region of endoderm. An alternative hypothesis, that the phenotype reflects an effect on GFP gene expression only, is not compatible with the large effect on the transcriptome we detect in $P d x^{-/-}$mutants, including altered expression of genes encoding digestive enzymes and other gut markers. Since overall shape and size of the gut seems normal, we suggest that $P d x$ mutation has caused cells in one region of the gut to be transformed to another endodermal cell type, invoking $P d x$ in cell determination functions.

A gut phenotype is also evident in amphioxus $C d x$ mutants, specifically the failure of the anus to open. Opening of the anus in amphioxus development involves rearrangement of cell junctions within epithelial cell layers; cells at the extreme posterior of the gut must lessen connections with neighbours and form new junctions with outer epidermal cells. In this way, two nested epithelial cell layers (gut and epidermis) become contiguous, with the edges of the anus opening marking the boundary where the two layers fused. In terms of geometry, this marks a topological transition from an indented sphere to a torus [76]. Biologically, the propensity to break and reform epithelial cell junctions must be a property specific to the extreme posterior cells of the gut (and/or the epidermis). Hence, loss of this property in $C d x$ mutant larvae likely reflects a change in cell fate specification, with terminal gut cells losing a region-specific character.

Transcriptome analysis allowed further insight into gut-related functions. We found that a set of 'gutenriched' genes was disproportionately represented among the (up and down) differentially regulated genes in both $P d x$ and $C d x$ mutant animals; for $P d x$, these include genes encoding homologues of vertebrate digestive proteins. The true number of gut-associated genes affected is likely to be even higher, since our definition of 'gut-enriched' is relatively strict. This enrichment further indicates that correct development of the gut, with functional regionalisation, is severely perturbed in $P d x$ and $C d x$ mutants.

We also asked if amphioxus $P d x$ and $C d x$ genes have roles in tissues outside the gut, because $P d x$ is also expressed in the first Hesse organ receptor cells to form and $C d x$ is expressed in all germ layers at the posterior of the embryo [1]. Hesse organ receptors are primary rhabdomeric photoreceptors and express the amphioxus melanopsin (Mop) gene encoding the microvillar light transducing protein $[77,78]$. We find that mutation of the $P d x$ gene did not remove Mop expression from Hesse organ receptor cells and the associated Mitf-positive pigment cell also formed. As in Xenopus [19], we find that disruption of $C d x$ function in amphioxus has a colinear-like effect on Hox genes. Morphological impacts of such change, such as homeotic transformations, are difficult to detect because of the lack of overt 
anatomical differences along the segmented mesoderm. We do detect cell fate change in the posterior epidermis in $C d x$ mutants, however, manifest as a smaller region of the epidermis expressing the Rootletin gene. The protein product of this gene drives cell shape changes underpinning tail fin development [50-52]; hence, this change in epidermal cell fate has a direct effect on larval morphology.

The other major developmental process in which $C d x$ genes are implicated in a range of taxa is posterior growth of the body or axial elongation. This role for $C d x$ is well characterised in vertebrates, and a similar function is evident in some arthropods, although homology of the process between distant taxa is not proven. We found that mutation of amphioxus $C d x$ dramatically disrupts growth of the body axis, as in vertebrates and some arthropods. We also detect some mechanistic similarities to vertebrates. The most important effectors through which $C d x$ genes control tail extension in vertebrates are central Hox genes and the retinoic acid (RA), FGF and Wnt signalling pathways [57, 58, 67, 68]. The role of vertebrate Hox genes in axial extension is complex. Although mouse Hox gene mutants do not generally have a tail phenotype (apart from Hoxb13 [79]), ectopic expression of central genes, such as Hoxa5 or $H o x b 8$, can partially rescue the tail truncation phenotype of $C d x$ mutants [68]. An opposite effect was found for Hoxa13, Hoxb13 and Hoxc13 suggesting a role for the extreme posterior Hox genes in tail growth termination $[68,80]$. Furthermore, there is evidence that $C d x 2$ is a direct activator of posterior and central Hox genes and these likely stimulate axial growth [41-43]. In amphioxus, we do not have definitive evidence for Hox gene involvement in tail development, but our finding of activation of central Hox genes by $C d x$ is consistent with this possibility and comparable to vertebrates.

There are clear similarities between amphioxus and vertebrate $C d x$ genes with respect to RA signalling in the tail. Low posterior levels of RA are necessary for tail growth in vertebrates [81-83] and amphioxus [51]. We show that $C d x$ is upstream of RA activity in amphioxus, as it is in vertebrates, since inhibition of RA action partially rescues the axial truncation and reduced tail fin phenotype of $C d x$ mutants. Young et al. [68] found that mutation of mouse $C d x 2$ and $C d x 4$ genes causes a downregulation of the gene encoding an RA-clearing enzyme Cyp26A1. Savory et al. [57] found this is a direct transcriptional effect and that it impacts RA signalling. Similarly, we find downregulation of expression of a Cyp26 gene in amphioxus $C d x$ mutants and show this is also likely to be a direct transcriptional effect. The clear inference is that in both mice and amphioxus, $C d x$ genes suppress RA signalling in the tail through the same mechanism, activation of Cyp26 expression, thereby permitting axis extension. There may be a second route by which amphioxus $C d x$ dampens posterior RA signalling, through positive regulation of genes encoding putative RA-binding proteins (iLBP4 and iLBP6), although currently it is unclear if these proteins bind RA or another molecule. We also note differences to vertebrates. In particular, we do not detect altered expression of genes encoding FGF or Wnt signalling components in amphioxus $C d x$ mutants. This is consistent with the findings of Bertrand et al. [84], who showed that in amphioxus (unlike vertebrates) FGF does not act as an antagonist to RA signalling during posterior axial extension.

\section{Conclusions}

We conclude that $P d x$ and $C d x$ genes are essential for regional cell fate specification in the endoderm of the developing amphioxus gut, including specification of midgut and formation of an anus. Combining with data from other taxa, specification of cell fates in the middle and posterior of the gut has probably been a function of $P d x$ and $C d x$ genes since the origin of Bilateria. This conclusion is consistent with the proposal that these two ParaHox genes played a role in the evolution of a through-gut, an innovation of the bilaterians and a possible contributor to sedimentary mixing and animal diversification in the Cambrian $[1,20]$. We also conclude that a role for $C d x$ in posterior axial extension is homologous between amphioxus and vertebrates, with similar mechanistic basis, and thus dates back at least to the base of Chordata. This second role for $C d x$ may have facilitated the evolution of the extended post-anal tail and active locomotion in chordates.

\section{Methods}

Amphioxus culture and targeted mutation

Amphioxus (Branchiostoma floridae) were obtained from a stock maintained by Jr-Kai Yu originating from Tampa, Florida. Cultures were maintained in Xiamen University under previously described conditions [85]. Gametes were obtained using thermal-shock (20 to $26^{\circ} \mathrm{C}$ ) [86]; fertilisation and culturing of embryos at $26^{\circ} \mathrm{C}$ was carried out as described [87]. The TALEN method was used to generate $P d x$ and $C d x$ mutants with TALEN pairs designed to target coding sequence (Additional file 1: Fig. S1-S6). TALEN construct assembly, mRNA sythesis and mutation efficacy assays were conducted following published methods [48]. Mosaic founder animals were spawned to generate F1 heterozygotes, using PCR and sequencing to detect, characterise and follow mutant alleles [49] (Additional file 1: Table S1). Homozygous mutants were generated by crossing heterozygous animals. 


\section{Whole-mount in situ hybridisation (WMISH)}

Coding sequences of $C d x, P d x$, Rootletin, Ilp1, Mop, Mitf and Cyp26-3 genes were amplified from cDNA libraries from amphioxus embryos using primers given in Additional file 1: Table S2. PCR products were cloned into the pGEM-T Easy vector (Promega, USA) and confirmed by DNA sequencing; the resultant plasmids were linearised, cleaned using phenol-chloroform and used for templated synthesis of digoxigenin-labelled antisense RNA probes using T7 or SP6 RNA polymerase (Promega, USA). Embryos and larvae were fixed in $4 \%$ paraformaldehyde in MOPS buffer at $4{ }^{\circ} \mathrm{C}$ for $24 \mathrm{~h}$ and stored in $70 \%$ ethanol at $-20{ }^{\circ} \mathrm{C}$. Hybridisation and detection was performed as described [88]; genotypes were checked by PCR after hybridisation and imaging.

\section{Scanning electron microscopy (SEM) and GFP detection}

SEM used an adaptation of published methods [89]. In brief, embryos were fixed in $2.5 \%$ glutaraldehyde in PBS at $4{ }^{\circ} \mathrm{C}$ overnight, washed $3 \times 10 \mathrm{~min}$ in $0.1 \mathrm{M} \mathrm{PBS}(\mathrm{pH}$ 7.4) and transferred to $100 \%$ ethanol through a graded ethanol series. Specimens were then washed $5 \times 10 \mathrm{~min}$ in $100 \%$ tertiary butyl alcohol and stored at $4{ }^{\circ} \mathrm{C}$ overnight. Samples were dried in a vacuum freeze dryer, placed on conductive tape, sprayed with platinum and observed under JSM-6390 scanning electron microscope. For GFP detection, amphioxus larvae were mounted in $1 \%$ methylcellulose in seawater and photographed under an SZX10 fluorescent stereoscope (Olympus, Japan) or an LSM 780 confocal microscope (Zeiss, Germany).

\section{BMS493 treatment}

The retinoic acid antagonist BMS493 (Sigma Aldrich) was dissolved in DMSO as a $1 \mathrm{mM}$ stock solution. Stock solution was diluted in filtered seawater to $1 \mu \mathrm{M}$ and applied to amphioxus embryos from $5 \mathrm{~h}$ post-fertilisation onwards (early gastrula stage). Control embryos were treated with filtered seawater containing an equal amount of DMSO. Most embryos were washed and fixed at 16 or $18 \mathrm{~h}$ post-fertilisation for in situ hybridisation; others were continuously cultured in BMS493 until $30 \mathrm{~h}$ post-fertilisation for morphological observation.

\section{Reporter gene assays}

A 3.1-kb region 5' of Cyp26-3 was cloned upstream of the firefly luciferase gene in pGL3 (Promega) and modified by PCR to generate three mutant versions with altered Cdx-binding sites (Additional file 1: Table S3). Solutions containing $3 \mathrm{ng} / \mu \mathrm{L}$ Renilla luciferase vector pRL-TK (Promega), 20\% glycerol, $5 \mathrm{mg} / \mathrm{ml}$ Texas Red Dextran, with or without $30 \mathrm{ng} / \mu \mathrm{L}$ of one of the Cyp263 constructs, were microinjected into unfertilised $B$. floridae eggs as previously described [87]. For each experiment, $\sim 60$ embryos were collected and assayed at $16 \mathrm{~h}$ post-fertilisation; uninjected embryos from the same batch were used as negative control. Levels of firefly luciferase from pGL3 and Renilla luciferase from pRL-TK were detected with the Dual Luciferase Kit (Promega) using a GloMax luminometer with an integration of 10 $\mathrm{s}$; the level of firefly luciferase was normalised to Renilla luciferase activity for each experiment. All experiments were repeated three times (Additional file 1: Table S4).

\section{Embryo genotyping}

Genotyping of live embryos was performed as previously described [49], and genotyping of embryos fixed with $4 \%$ PFA-MOPS-EGTA or analysed by whole-mount in situ hybridisation was conducted with the same protocol except that an extra 30-min wash in $500 \mathrm{ml}$ filtered seawater or PBS was added before lysis, to remove the fixative.

\section{RNA sequencing}

Embryos and larvae obtained from crosses between $P d x^{+/-} 4 \Delta \times P d x^{+/-} 11 \Delta$ and $C d x^{+/-} 7 \Delta \times C d x^{+/-} 7 \Delta$ were sorted by visual phenotype at the 5 gill slit stage for $P d x$ and 2-3 gill slits (34 h or $42 \mathrm{~h}$ post-fertilisation) for $C d x$. Samples for RNA analysis were pools of $\sim 100$ $(P d x)$ or $\sim 300(C d x)$ embryos or larvae. Each cross gave two matched sibling pools: 'mutant' individuals with a morphological phenotype (inferred $P d x 4 \Delta / 11 \Delta$ and $C d x$ $7 \Delta / 7 \Delta$ ) and 'control' individuals without clear phenotype (mixture of heterozygotes and wild type). RNA sequencing was performed by BGI (Shenzhen, China) on the BGISEQ platform, $>60$ million 100 nt paired-end reads per sample, using mRNA enrichment, random priming reverse transcription and low PCR cycle number; initial total RNA ranged from 1.11 to $2.17 \mu \mathrm{g}$ (RIN 10.0) for $P d x$ and 0.69 to $1.89 \mu \mathrm{g}$ (RIN 8.7 to 10 ) for $C d x$. Reads were mapped using STAR v2.7.0 [90] using --twopassmode Basic and --outSJfilterOverhangMin $12 \quad 12 \quad 12 \quad 12$ options [91] to B. floridae superTranscriptome BfsuperV5 (215,490 superTranscripts) downloaded from the IncDNA-BF database [92]; genes may be represented by more than one contig. Hox genes were assembled manually to remove and correct an artefactual fusion between 6 distinct Hox genes and a lncRNA (giving 215,495 superTranscripts [93];). Between 45.2 and 52.4 million reads per sample were mapped. Since superTranscripts can join exons not normally spliced together, STAR aligner settings were adjusted to permit mapping near non-canonical splice junctions (STAR --quantMode GeneCounts --twopassMode Basic --outSJfilterOverhangMin 121212 12). STAR mapped 91\% and 90\% of reads from the $P d x$ and $C d x$ experiments. Reads were quantified using featureCounts [94] in the Subread package v1.6.3 allowing multiple mapping, thereby permitting 
analysis of duplicate genes (featureCounts $-\mathrm{O}-\mathrm{M}-\mathrm{p}-\mathrm{B}$ -fraction).

\section{Differential gene expression analysis}

Analysis of differentially expressed genes (DEGs) used DESeq2 v3.8 [95] including principal component analysis to test for outlier samples and batch effects. In the $C d x$ experiment, two control and two mutant 42-h samples grouped distinctly from one control and one mutant 34 $\mathrm{h}$ sample, likely due to a batch or developmental age effect. Two DEG analyses were therefore performed, $42 \mathrm{~h}$ alone and $34 \mathrm{~h} / 42 \mathrm{~h}$ combined (Additional file 1: Fig. S17). In the $P d x$ experiment, one control sample (WT2) grouped distinctly and was excluded from DEG analysis which used 3 mutant and 2 control samples (Additional file 1: Fig. S18). For a contig to be considered differentially expressed, we required expression change of $>0.5$ $\log _{2}$ (fold change) and adjusted $p$ value $<0.05$, plus absolute expression level of $>2 \mathrm{fpkm}$ in at least one condition [19]. To assess the accuracy of embryo sorting, raw reads matching mutant or wild type allele sequences were counted. Embryo pools classed as $C d x^{-1-}$ had 4.3 to $5.3 \%$ of $C d x$ 'wild type' reads, suggesting that 1 or 2 embryos in each mutant pool of 20 were heterozygous; the control pool had 38 to $70 \%$ wild type reads, consistent with a mix of heterozygous and genetic wild type embryos. The same method could not be applied accurately to $P d x$ mutants because control pools had predominantly wild type reads (91 to 100\%), suggesting downregulation of mutant allele expression in heterozygotes. This obviates the applicability of read counts for assessing heterozygote number. Gut-enriched genes were identified from published B. lanceolatum data [69] (NCBI GEO GSE106430) as genes with higher mean expression level in the gut than any other adult tissue (eggs and embryos excluded) and expression level in the gut at least double that in 7 out of 8 other adult tissues; the 2083 genes were matched to contigs in the current study using blastn with an $e$ value cut off of 1e-70 giving 4705 gut-enriched contigs.

\section{Supplementary information}

Supplementary information accompanies this paper at https://doi.org/10. 1186/s12915-020-00796-2.

Additional file 1: Figs. S1-S22, Tables S1-S9. Gene structures of amphioxus $P d x$ and $C d x$ genes (Fig. S1-S2). Generation of mutations in amphioxus $P d x$ and $C d x$ genes (Fig. S3-S9, Table S1). Gene cloning primers (Table S2). Morphology of $P d x$ and $C d x$ mutant amphioxus (Fig. S10-S13). Analysis of amphioxus Cyp26 genes (Fig. S14-S16, Tables S3-S4). Differential Gene Expression analysis from transcriptome data (Fig. S17S21, Tables S5-S8). Effect of mutation of amphioxus $P d x$ and $C d x$ on gutexpressed genes (Fig. S22, Table S9).

Additional file 2: Supplementary Data. Gene expression differences between mutant and wild type amphioxus inferred from mapping RNAseq reads to superTranscriptome. Contig identity, expression fold change, FPKM, raw read counts and DNA sequence are given for $C d x$ gene mutation analysis ( $42 \mathrm{~h}$ dataset; $34 \mathrm{~h}$ and $42 \mathrm{~h}$ datasets) and $P d x$ mutation analysis. Data underlying identification of gut-enriched genes in $B$. lanceolatum, inference of inferred B. floridae orthologues, presence in $P d x$ and $C d x$ differential gene expression datasets and putative gene identities.

\section{Acknowledgements}

We thank Enrico D'Aniello, Salvatore D'Aniello, José Luis Gómez-Skarmeta, Sebastian Shimeld, Rodrigo Pracana, Ricard Albalat, Zhiliang Ji and Thurston Lacalli for the advice and discussion, and Caiming Wu for help with scanning electron microscopy.

\section{Authors' contributions}

YZ and GL generated amphioxus mutants, performed in situ hybridisations, experimental manipulations and morphological analyses; $\mathrm{CHU}$ and $\mathrm{PWHH}$ undertook transcriptomic analysis with input from JGF. Experiments were designed by $\mathrm{GL}$ and $\mathrm{PWHH}$ who also wrote the first draft of the manuscript. The authors read and approved the final manuscript.

\section{Funding}

This research was funded by the Elizabeth Hannah Jenkinson fund, QR Global Challenges Research Fund to the University of Oxford, National Natural Science Foundation of China (No. 31872186); Fundamental Research Funds for the Central Universities, China (No. 20720160056); Ministry of Science, Innovation and Universities, Spanish Government (BFU2017-86152$\mathrm{P})$; and a predoctoral FPI contract from the Ministry of Science, Innovation and Universities, Spanish Government, to C.H.-U.

\section{Availability of data and materials}

Mutant and wild type RNAseq datasets generated during the current study have been deposited in NCBI SRA (accessions SRX7351856 to SRX7351867) linked to BioProject PRJNA594548 [96]. The superTranscriptome used for mapping, modified from IncDNA-BF, has been deposited in ORA-Data [93]. The DNA sequences of all contigs passing thresholds for inclusion in analysis, read mapping counts and RPKM values for each experiment are given in Additional file 2: Supplementary Data.

\section{Ethics approval and consent to participate}

Not applicable

\section{Consent for publication}

Not applicable

\section{Competing interests}

The authors declare that they have no competing interests.

\section{Author details}

${ }^{1}$ State Key Laboratory of Cellular Stress Biology, School of Life Sciences, Xiamen University, Xiamen, China. ${ }^{2}$ Department of Zoology, University of Oxford, Oxford OX1 3SZ, UK. ${ }^{3}$ Department of Genetics, Microbiology \& Statistics, and Institute of Biomedicine (IBUB), University of Barcelona, 08028 Barcelona, Spain.

Received: 8 December 2019 Accepted: 19 May 2020

Published online: 16 June 2020

References

1. Brooke NM, Garcia-Fernàndez J, Holland PWH. The ParaHox gene cluster is an evolutionary sister of the Hox gene cluster. Nature. 1998;392:920-2.

2. Ferrier DEK, Dewar K, Cook A, Chang JL, Hill-Force A, Amemiya C. The chordate ParaHox cluster. Curr Biol. 2005;15:R820-2.

3. Mulley JF, Chiu C-H, Holland PWH. Breakup of a homeobox cluster after genome duplication in teleosts. PNAS. 2006:103:10369-72.

4. Illes JC, Winterbottom E, Isaacs HV. Cloning and expression analysis of the anterior ParaHox genes Gsh1 and Gsh2 from Xenopus tropicalis. Devel Dynamics. 2009;238:194-203.

5. Annunziata R, Martinez P, Arnone MI. Intact cluster and chordate-like expression of ParaHox genes in a sea star. BMC Biol. 2013;11:68. 
6. Ikuta T, Chen Y-C, Anunziata R, Ting H-C, Tung CH, Koyanagi R, Tagawa K, Humphreys T, Fujiyama A, Saiga H, Satoh N, Yu J-K, Arnone Ml, Su Y-H. Identification of an intact ParaHox cluster with temporal colinearity but residual spatial colinearity in the hemichordate Ptychodera flava. BMC Evol Biol. 2013;13:129

7. Takeuchi T, Koyanagi R, Gyoja F, Kanda M, Hisata K, Fujie M, Goto H, Yamasaki S, Nagai K, Morino Y, Miyamoto H, et al. Bivalve-specific gene expansion in the pearl oyster genome: implications of adaptation to a sessile lifestyle. Zoological Lett. 2016;2:3.

8. Wang S, Zhang J, Jiao W, Li J, Xun X, Sun Y, Guo X, Huan P, Dong B, Zhang $L$, Hu $X$, et al. Scallop genome provides insights into evolution of bilaterian karyotype and development. Nature Ecol Evol. 2017;1:0120.

9. Hui JH, Raible F, Korchagina N, Dray N, Samain S, Magdelenat G, Jubin C, Segurens B, Balavoine G, Arendt D, Ferrier DEK. Features of the ancestral bilaterian inferred from Platynereis dumerilii ParaHox genes. BMC Biol. 2009;7:43.

10. Garstang M, Ferrier DEK. Time is of the essence for ParaHox gene clustering. BMC Biol. 2013;11:72.

11. Wright CVE, Schnegelsberg P, De Robertis EM. XIHbox 8: a novel Xenopus homeo protein restricted to a narrow band of endoderm. Development. 1988;105:787-94.

12. Offield MF, Jetton TL, Labosky PA, Ray M, Stein RW, Magnuson MA, Hogan BLM, Wright CVE. PDX-1 is required for pancreatic outgrowth and differentiation of the rostral duodenum. Development. 1996;122:983-95.

13. Holland AM, Garcia S, Naselli G, MacDonald RJ, Harrison LC. The Parahox gene $P d x 1$ is required to maintain positional identity in the adult foregut. Int J Devel Biol. 2013;57:391-8.

14. Osborne PW, Benoit G, Laudet V, Schubert M, Ferrier DEK. Differential regulation of ParaHox genes by retinoic acid in the invertebrate chordate amphioxus (Branchiostoma floridae). Devel Biology. 2009;327:252-62.

15. Yu JK, Meulemans D, McKeown SJ, Bronner-Fraser M. Insights from the amphioxus genome on the origin of vertebrate neural crest. Genome Res. 2008;18:1127-32.

16. Lacalli T, Stach T. Acrania (Cepahlochordata). In: Structure and evolution of invertebrate nervous systems (Schmidt-Rhaesa A, Harzsch S, Purschke G eds.) Oxford University Press, Oxford. 2016; pp 719-728.

17. Beck F, Erler T, Russell A, James R. Expression of Cdx-2 in the mouse embryo and placenta: possible role in patterning of the extra-embryonic membranes. Devel Dyn. 1995;204:219-27.

18. van den Akker E, Forlani S, Chawengsaksophak K, de Graaff W, Beck F, Meyer Bl, Deschamps J. Cdx1 and Cdx2 have overlapping functions in anteroposterior patterning and posterior axis elongation. Development. 2002;129:2181-93.

19. Marlétaz F, Maeso I, Faas L, Isaacs HV, Holland PWH. Cdx ParaHox genes acquired distinct developmental roles after gene duplication in vertebrate evolution. BMC Biol. 2015;13:56

20. Holland PWH. Did homeobox gene duplications contribute to the Cambrian explosion? Zoological Lett. 2015;1:1.

21. Garcia-Fernàndez J. The genesis and evolution of homeobox gene clusters. Nature Rev Gen. 2005;6:881-92

22. Cole AG, Rizzo F, Martinez P, Fernandez-Serra M, Arnone MI. Two ParaHox genes, SpLox and SpCdx, interact to partition the posterior endoderm in the formation of a functional gut. Development. 2009;136:541-9.

23. Samadi L, Steiner G. Conservation of ParaHox genes' function in patterning of the digestive tract of the marine gastropod Gibbula varia. BMC Devel Biol. 2010;10:74

24. Holland PWH. Major transitions in animal evolution: a developmental genetic perspective. Amer Zool. 1998;38:829-42.

25. Hejnol A, Martín-Durán JM. Getting to the bottom of anal evolution. Zool Anz. 2015;256:61-74.

26. Jonsson J, Carlsson L, Edlund T, Edlund H. Insulin-promoter-factor 1 is required for pancreas development in mice. Nature. 1994;371:606-9.

27. Stoffers DA, Zinkin NT, Stanojevic V, Clarke WL, Habener JF. Pancreatic agenesis attributable to a single nucleotide deletion in the human IPF1 gene coding sequence. Nature Genet. 1997;15:106-10.

28. Schwitzgebel VM, Mamin A, Brun T, Ritz-Laser B, Zaiko M, Maret A, Jornayvaz FR, Theintz GE, Michielin O, Melloul D, Philippe J. Agenesis of human pancreas due to decreased half-life of insulin promoter factor 1. J Clin Endocrinology \& Metab. 2003;88:4398-406.

29. Grapin-Botton A, Majithia AR, Melton DA. Key events of pancreas formation are triggered in gut endoderm by ectopic expression of pancreatic regulatory genes. Genes Dev. 2001;15:444-54.
30. Annunziata R, Arnone Ml. A dynamic regulatory network explains ParaHox gene control of gut patterning in the sea urchin. Development. 2014;141: 2462-72.

31. Wang $X$, et al. Genome-wide analysis of PDX1 target genes in human pancreatic progenitors. Molecular Metab. 2018;9:57-68.

32. Beck F, Chawengsaksophak K, Waring P, Playford RJ, Furness JB. Reprogramming of intestinal differentiation and intercalary regeneration in Cdx2 mutant mice. Proc Natl Acad Sci U S A. 1999;96:7318-23.

33. Wu LH, Lengyel JA. Role of caudal in hindgut specification and gastrulation suggests homology between Drosophila amnioproctodeal invagination and vertebrate blastopore. Development. 1998;125:2433-42.

34. Edgar LG, Carr S, Wang H, Wood WB. Zygotic expression of the caudal homolog pal-1 is required for posterior patterning in Caenorhabditis elegans embryogenesis. Devel Biol. 2001;229:71-88.

35. Chawengsaksophak K, de Graaff W, Rossant J, Deschamps J, Beck F. Cdx2 is essential for axial elongation in mouse development. Proc Natl Acad Sci U S A. 2004;101:7641-5.

36. Shimizu T, Bae YK, Muraoka O, Hibi M. Interaction of Wht and caudal-related genes in zebrafish posterior body formation. Devel Biol. 2005;279:125-41.

37. Faas I, Isaacs HV. Overlapping functions of $C d \times 1, C d \times 2$, and $C d \times 4$ in the development of the amphibian Xenopus tropicalis. Devel Dynamics. 2009; 238:835-52

38. Katsuyama $Y$, Sato $Y$, Wada $S$, Saiga $H$. Ascidian tail formation requires caudal function. Devel Biol. 1999;213:257-68.

39. Copf T, Schröder R, Averof M. Ancestral role of caudal genes in axis elongation and segmentation. Proc Natl Acad Sci U S A. 2004;101:17711-5.

40. Shinmyo Y, Mito T, Matsushita T, Sarashina I, Miyawaki K, Ohuchi H, Noji S. caudal is required for gnathal and thoracic patterning and for posterior elongation in the intermediate-germband cricket Gryllus bimaculatus. Mech Devel. 2005;122:231-9.

41. Charité J, de Graaff W, Consten D, Reijnen MJ, Korving J, Deschamps J. Transducing positional information to the Hox genes: critical interaction of cdx gene products with position-sensitive regulatory elements. Development. 1998;125:4349-58.

42. Subramanian V, Meyer BI, Gruss P. Disruption of the murine homeobox gene $\mathrm{Cdx} 1$ affects axial skeletal identities by altering the mesodermal expression domains of Hox genes. Cell. 1995;83:641-53.

43. Isaacs HV, Pownall ME, Slack JM. Regulation of Hox gene expression and posterior development by the Xenopus caudal homologue Xcad3. EMBO J. 1998:17:3413-27.

44. Moreno E, Morata G. Caudal is the Hox gene that specifies the most posterior Drosophila segment. Nature. 1999;400:873-7.

45. Hunter CP, Harris JM, Maloof JN, Kenyon C. Hox gene expression in a single Caenorhabditis elegans cell is regulated by a caudal homolog and intercellular signals that inhibit wnt signaling. Development. 1999;126:805-14.

46. Kulakova MA, Bakalenko N, Novikova E, Cook CE, Eliseeva E, Steinmetz PRH, Kostyuchenko RP, Dondua A, Arendt D, Akam M, Andreeva T. Hox gene expression in the larval development of the polychaetes Nereis virens and Platynereis dumerilii (Annelida, Lophotrochozoa). Dev Genes Evol. 2007;217: 39-54.

47. Wollesen T, Monje SV, McDougall C, Degnan BM, Wanninger A. The ParaHox gene Gsx patterns the apical organ and central nervous system but not the foregut in scaphopod and cephalopod mollusks. Evodevo. 2015;6:41.

48. Li G, Feng J, Lei Y, Wang J, Wang H, Shang L-K, Liu D, Zhao H, Zhu Y, Wang $Y$. Mutagenesis at specific genomic loci of amphioxus Branchiostoma belcheri using TALEN method. J Genet Genomics. 2014;41:215-9.

49. Li G, Liu X, Xing C, Zhang H, Shimeld SM, Wang Y. Cerberus-Nodal-Lefty-Pitx signaling cascade controls left-right asymmetry in amphioxus. PNAS. 2017; 14(14):3684-9.

50. Flood PR. Fine structure of the notochord of amphioxus. Symp Zoolog Soc Lond. 1975;36:81-104.

51. Koop D, Holland LZ, Setiamarga D, Schubert M, Holland ND. Tail regression induced by elevated retinoic acid signaling in amphioxus larvae occurs by tissue remodeling, not cell death. Evolution Devel. 2011;13:427-35.

52. Mansfield $\mathrm{JH}, \mathrm{Holland}$ ND. Amphioxus tails: source and fate of larval fin rays and the metamorphic transition from an ectodermal to a predominantly mesodermal tail. Acta Zool. 2015;96:117-25.

53. Carvalho JE, Theodosiou M, Chen J, Chevret P, Alvarez S, De Lera AR, Laudet $V$, Croce JC, Schubert M. Lineage-specific duplication of amphioxus retinoic acid degrading enzymes (CYP26) resulted in sub-functionalization of patterning and homeostatic roles. BMC Evol Biol. 2017;17:24. 
54. Thatcher JE, Isoherranen $\mathrm{N}$. The role of CYP26 enzymes in retinoic acid clearance. Expert Opinion on Drug Metab Tox. 2009;5:875-86.

55. Cañestro C, Postlethwait JH, Gonzàlez-Duarte R, Albalat R. Is retinoic acid genetic machinery a chordate innovation? Evolution Development. 2006;8:394-406.

56. Albalat $R$, Brunet $F$, Laudet $V$, Schubert $M$. Evolution of retinoid and steroid signaling: vertebrate diversification from an amphioxus perspective. Genome Biol Evol. 2011;3:985-1005.

57. Savory JG, Bouchard N, Pierre V, Rijli FM, De Repentigny Y, Kothary R, Lohnes D. Cdx2 regulation of posterior development through non-Hox targets. Development. 2005;136:4099-110.

58. Amin S, Neijts R, Simmini S, van Rooijen C, Tan SC, Kester L, van Oudenaarden A, Creyghton MP, Deschamps J. Cdx and T Brachyury coactivate growth signaling in the embryonic axial progenitor niche. Cell Rep. 2016;17:3165-77.

59. Dobbs-McAuliffe B, Zhao Q, Linney E. Feedback mechanisms regulate retinoic acid production and degradation in the zebrafish embryo. Mech Devel. 2004:121:339-50.

60. Emoto Y, Wada H, Okamoto H, Kudo A, Imai Y. Retinoic acid-metabolizing enzyme Cyp26a1 is essential for determining territories of hindbrain and spinal cord in zebrafish. Devel Biology. 2005;278:415-27.

61. D'Aniello E, Rydeen AB, Anderson JL, Mandal A, Waxman JS. Depletion of retinoic acid receptors initiates a novel positive feedback mechanism that promotes teratogenic increases in retinoic acid. PLoS Genet. 2013;9: e1003689.

62. Bomati EK, Manning G, Deheyn DD. Amphioxus encodes the largest known family of green fluorescent proteins, which have diversified into distinct functional classes. BMC Evol Biol. 2009;9:77.

63. Li G, Zhang QJ, Zhong J, Wang YQ. Evolutionary and functional diversity of green fluorescent proteins in cephalochordates. Gene. 2009;446:41-9.

64. Pashmforoush M, Chan SJ, Steiner DF. Structure and expression of the insulin-like peptide receptor from amphioxus. Molec Endocrinology. 1996; 10:857-66.

65. Holland LZ, et al. The amphioxus genome illuminates vertebrate origins and cephalochordate biology. Genome Res. 2008;18:1100-11.

66. Jackman WR, Mougey JM, Panopoulou GD, Kimmel CB. crabp and maf highlight the novelty of the amphioxus club-shaped gland. Acta Zool. 2004; 85:91-9.

67. Pownall ME, Tucker AS, Slack JM, Isaacs HV. eFGF, Xcad3 and Hox genes form a molecular pathway that establishes the anteroposterior axis in Xenopus. Development. 1996;122:3881-92.

68. Young T, Rowland JE, van de Ven C, Bialecka M, Novoa A, Carapuco M, van Nes J, de Graaff W, Duluc I, Freund JN, Beck F. Cdx and Hox genes differentially regulate posterior axial growth in mammalian embryos. Dev Cell. 2009:17:516-26.

69. Marlétaz F, et al. Amphioxus functional genomics and the origins of vertebrate gene regulation. Nature. 2018;564:64-70.

70. Wada H, Garcia-Fernàndez J, Holland PWH. Colinear and segmental expression of amphioxus Hox genes. Devel Biology. 1999;213:131-41.

71. Schubert M, Holland ND, Laudet V, Holland LZ. A retinoic acid-Hox hierarchy controls both anterior/posterior patterning and neuronal specification in the developing central nervous system of the cephalochordate amphioxus. Devel Biol. 2006;296:190-202.

72. Holland PWH, Patton SJ, Brooke NM, Garcia-Fernandez J. Genetic patterning of the ectoderm and endoderm in amphioxus: from homeobox genes to hormones. In: Kawashima S, Kikuyama S, editors. Advances in Comparative Endocrinology, Proceedings of the 13th International Congress on Comparative Endocrinology; 1997. p. 247-52.

73. Lecroisey C, Le Pétillon Y, Escriva H, Lammert E, Laudet V. Identification, evolution and expression of an insulin-like peptide in the cephalochordate Branchiostoma lanceolatum. PLoS One. 2015;10:e0119461.

74. Ohneda K, Ee H, German M. Regulation of insulin gene transcription. Semin Cell Devel Biol. 2000;11:227-33.

75. Deheyn DD, Kubokawa K, McCarthy JK, Murakami A, Porrachia M, Rouse GW, Holland ND. Endogenous green fluorescent protein (GFP) in amphioxus. Biol Bull. 2007;213:95-100.

76. Jockusch $H$, Dress A. From sphere to torus: a topological view of the metazoan body plan. Bull Math Biol. 2003;65:57-65.

77. Koyanagi M, Kubokawa K, Tsukamoto H, Shichida Y, Terakita A. Cephalochordate melanopsin: evolutionary linkage between invertebrate visual cells and vertebrate photosensitive retinal ganglion cells. Curr Biol. 2005;15:1065-9
78. Pantzartzi CN, Pergner J, Kozmikova I, Kozmik Z. The opsin repertoire of the European lancelet: a window into light detection in a basal chordate. Int J Devel Biology. 2017;61:763-72

79. Economides KD, Zeltser L, Capecchi MR. Hoxb13 mutations cause overgrowth of caudal spinal cord and tail vertebrae. Devel Biol. 2003;256: 317-30.

80. Aires R, de Lemos L, Nóvoa A, Jurberg AD, Mascrez B, Duboule D, Mallo M. Tail bud progenitor activity relies on a network comprising Gdf11, Lin28, and Hox13 genes. Dev Cell. 2019;48:383-95.

81. Ruiz i Altaba A, Jessell T. Retinoic acid modifies mesodermal patterning in early Xenopus embryos. Genes Dev. 1991;5:175-87.

82. Herrmann K. Teratogenic effects of retinoic acid and related substances on the early development of the zebrafish (Brachydanio rerio) as assessed by a novel scoring system. Toxicol in Vitro. 1995;9:267-83.

83. Padmanabhan R. Retinoic acid-induced caudal regression syndrome in the mouse fetus. Reprod Toxicol. 1998;12:139-51.

84. Bertrand S, Aldea D, Oulion S, Subirana L, De Lera AR, Somorjai I, Escriva H. Evolution of the role of RA and FGF signals in the control of somitogenesis in chordates. PLoS One. 1991;10:e0136587.

85. Li G, Yang X, Shu Z, Chen X, Wang Y. Consecutive spawnings of Chinese amphioxus, Branchiostoma belcheri, in captivity. PLoS One. 2012;7:e50838.

86. Li G, Shu Z, Wang Y. Year-round reproduction and induced spawning of Chinese amphioxus, Branchiostoma belcheri, in laboratory. PLoS One. 2013;8: e75461.

87. Liu X, Li G, Feng J, Yang X, Wang YQ. An efficient microinjection method for unfertilized eggs of Asian amphioxus Branchiostoma belcheri. Dev Genes Evol. 2013;223(4):269-78.

88. Yu JK, Holland LZ. Amphioxus whole-mount in situ hybridization. Cold Spring Harb Protoc. 2009;4:1-6.

89. Inoué $\mathrm{T}$, Osatake $\mathrm{H}$. A new drying method of biological specimens for scanning electron microscopy: the t-butyl alcohol freeze-drying method. Arch Histol Cytol. 1988;51:53-9.

90. Dobin A, Davis CA, Schlesinger F, Drenkow J, Zaleski C, Jha S, Batut P, Chaisson M, Gingeras TR. STAR: ultrafast universal RNA-seq aligner. Bioinformatics. 2013:29:15-21.

91. Davidson NM, Hawkins AD, Oshlack A. SuperTranscripts: a data driven reference for analysis and visualisation of transcriptomes. Genome Biol. 2017;18:148

92. Ji ZL, Li G, Qin YM. IncDNA-BF: Integrative CDNA library for Branchiostoma floridae. http://139.129.29.118/IncDNA/. Accessed 5 Jan 2019.

93. Holland PWH, Li G, Herrera-Úbeda C. Amphioxus (Branchiostoma floridae) superTranscriptome: modified transcriptome from IncDNA-BF. 2020. University of Oxford [doi: https://doi.org/10.5287/bodleian:Koj7zmB7j].

94. Liao Y, Smyth GK, Shi W. featureCounts: an efficient general purpose program for assigning sequence reads to genomic features. Bioinformatics. 2013;30:923-30.

95. Love Ml, Huber W, Anders S. Moderated estimation of fold change and dispersion for RNA-seq data with DESeq2. Genome Biol. 2014;15:550.

96. Zhong Y, Herrera-Úbeda C, Garcia-Fernàndez J, Li G, Holland PWH. RNA-seq of Branchiostoma floridae Pdx and Cdx mutants. 2020. NCBI BioProject PRJNA594548. [https://www.ncbi.nlm.nih.gov/bioproject/PRJNA594548].

\section{Publisher's Note}

Springer Nature remains neutral with regard to jurisdictional claims in published maps and institutional affiliations.

Ready to submit your research? Choose BMC and benefit from:

- fast, convenient online submission

- thorough peer review by experienced researchers in your field

- rapid publication on acceptance

- support for research data, including large and complex data types

- gold Open Access which fosters wider collaboration and increased citations

- maximum visibility for your research: over $100 \mathrm{M}$ website views per year

At $\mathrm{BMC}$, research is always in progress.

Learn more biomedcentral.com/submissions 